Список литературы:

1. Коваль С.П. Энергосбережение в административных зданиях: 52 способа. 07.12.2009г. Режим доступа: http://portal-energo.ru/articles/details/id/16 (дата обращения 23.11.2016). $\mathrm{T}$

2. Афонин А.М., Царегородцев Ю.Н., Петрова С.А., Петрова А.М. Энергосберегающие технологии в промышленности. - М.: Форум, 2011.

3. Карминский В.Д., Колесников В.И., Жданов Ю.А., Гарин В.М. Экологические проблемы и энергосбережение. - М: Маршрут, 2004.

4. Электроэнергетика России 2030: Целевое видение / Под общ. ред. Б.Ф. Вайнзихера. - М.: Альтпина Бизнес Букс, 2008.

5. Липатов Ю.А. Актуализация российского законодательства в области энергосбережения и энергоснабжения.

6. Энергосберегающие технологии [Электронный ресурс]. - Режим доступа:www:ritsu.ru/sn2 energosberegayuschie-tehnologii.html.

Задачи разработки системы автоматического управления электропривода для налива нефтепродуктов переработки нефти в цистерны подвижного состояния

Саввинова А.В., студентка,

Технический институт (филиал)

Северо-Восточного федерального университета, г. Нерюнгри

E-mail: nastya.savvinova.93@mail.ru

Научный руководитель: к.т.н., доцент Киушкина В.P.

Электропривод, являясь энергосиловой основой современного производства, потребляет около 60\% всей вырабатываемой электроэнергии, следовательно, основной эффект энергосбережения может быть получен в этой сфере. Большая часть электроэнергии потребляется электроприводами на основе повсеместно используемых асинхронных электродвигателей с короткозамкнутым ротором, для которых основным направлением энергосбережения является переход от нерегулируемого электропривода к регулируемому. Это направление принято в мировой практике и интенсивно развивается, чему активно способствуют два совпавших со времени события: наметившийся дефицит энергоресурсов и ощутимый рост их стоимости и выдающиеся успехи силовой электроники и микроэлектроники [1].

На решение этих задач направлен Федеральный закон «Об энергосбережении» от 3 апреля 1996 г. Федеральный закон регулирует отношения, возникающие в процессе деятельности в области энергосбережения, в целях создания экономических и организационных условий для эффективного использования энергетических ресурсов.

Для энергосбережения, одно из наиболее эффективных и быстроокупаемых, внедрение высокотехнологичной и наукоемкой энергосберегающей техники частотно-регулируемых асинхронных приводов, позволяющих оптимизировать режимы работы турбомеханизмов в широком диапазоне изменения нагрузок.

С появлением надежного регулируемого электропривода создались предпосылки для разработки принципиально новой технологии транспорта нефти или газа с плавным 
регулированием рабочих параметров насосной или вентиляторной установок без непроизводительных затрат электроэнергии и с широкими возможностями повышения точности и эффективности технологических критериев работы систем подачи.

Со времени энергетического кризиса, вызвавшего повышение в 70-80-е годы цен на энергоресурсы, исследовались возможности энергосбережения, в том числе у рабочих машин с квадратически изменяющимся моментом вращения по отношению к скорости вращения. С помощью регулирования частоты вращения изменение расхода электрической энергии по сравнению с дросселированием достигается с более значительным потенциалом сбережения энергии.

К настоящему моменту в мировой практике начинает широко использоваться частотно-управляемый асинхронный электропривод со стандартными короткозамкнутыми асинхронными электродвигателями общего применения. Это обусловлено появлением большого количества совершенных и относительно недорогих преобразователей частоты, построенных на современной элементной базе [2].

Таким образом, применение регулируемого электропривода турбомеханизмов позволяет создать новую технологию энергосбережения, в которой экономится не только электроэнергия, но и сберегается тепловая энергия и сокращается расход нефти.

При частотном регулировании насосов можно в значительной степени избежать аварийных ситуаций за счет предотвращения гидравлических ударов, возникающих при изменении режимов работы и пуске системы при нерегулируемом электроприводе. Поэтому проводимые работы по переводу турбомеханизмов на регулируемый электропривод являются актуальными.

Для решения задачи по оптимальному проектированию регулируемого электропривода необходимо учитывать специфические свойства приводимого механизма - его характеристики.

Необходимо создать автоматическую систему управления(АСУ), которая должна осуществлять контроль и управление всем технологическим процессом. Разработанная система управления должна осуществлять:

- повышение точности учета отгружаемых и хранимых продуктов;

- снижение трудоемкости управления технологическими операциями отпуска нефтепродуктов и минимизация ручного труда;

- повышение безопасности технологических операций;

- повышение информационного обеспечения технологического и эксплуатационного персонала;

- уменьшение материальных и энергетических затрат;

- создание основ для внедрения оптимизированных методов управления предприятием.

Достижение вышеозначенных целей будет способствовать также улучшению экологической обстановки в районах нефтеперерабатывающих заводов.

Таким образом для выполнения поставленных задач необходимо разработать систему автоматического управления электроприводом насоса для налива продуктов переработки нефтепродуктов в железнодорожные цистерны.

Технологическая схема, применяемая при операции налива приведена на рисунке 1. 


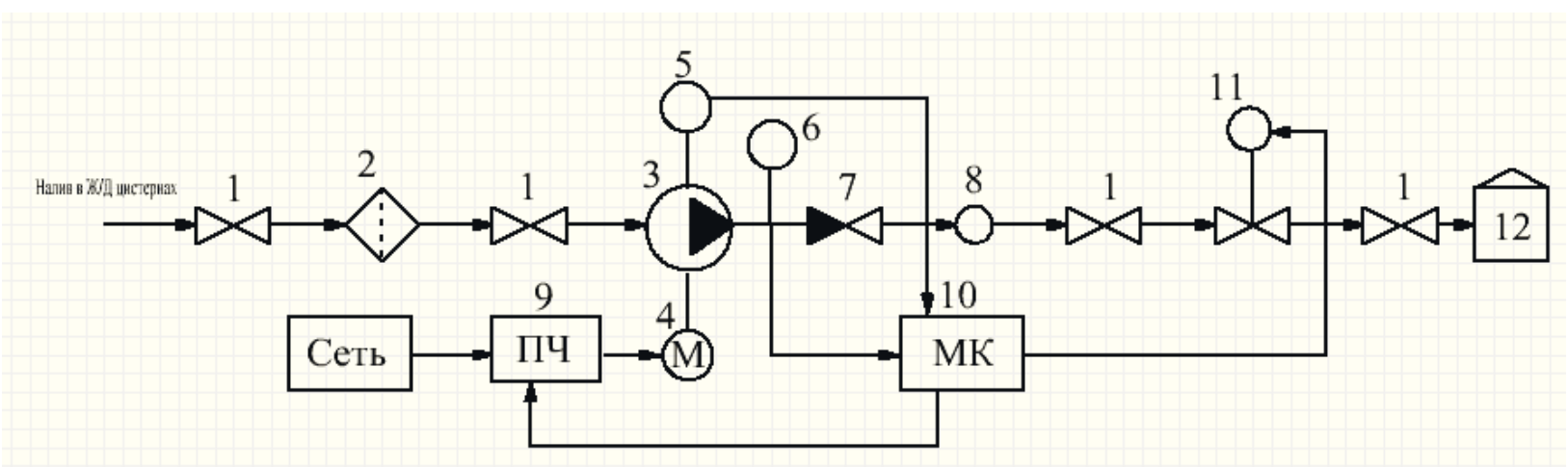

Рис. 1. Технологическая схема операции налива нефтепродуктов в резервуар входят: - ручной отсечной клапан (1); - сетчатый фильтр (2); - насосный агрегат (3); - устройство мягкого пуска или частотный преобразователь (4); - датчик температуры (5); - датчик давления (6); обратный клапан (7); - расходомер (8); -преобразователь частоты (9); - микроконтроллер (10) автоматический отсечной или регулируемый клапан (11); - резервуар (12)

Налив нефтепродуктов в ж/д цистерны осуществляется, как правило, по закрытой бесшланговой системе автоматизированных шарнирно-сочлененных или телескопических устройств, оборудованных автоматическими ограничителями налива, обеспечивающими предотвращение перелива цистерн, а также устройствами для герметизации налива с отводом паров в систему рекуперации.

Процедуры налива нефтепродуктов и используемые для них установки тактового налива в а/м цистерны во многом подобны процедурам налива нефтепродуктов и установкам налива в ж/д цистерны, поэтому одни и те же производители оборудования для автоматизации налива, как правило, изготавливают его для налива нефтепродуктов в оба типа цистерн.

Налив нефтепродуктов может производиться двумя способами: сверху и снизу.

Нижний налив нефтепродуктов имеет ряд преимуществ по сравнению с верхним наливом:

- повышение безопасности и облегчение работы оператора-наливщика;

- снижение опасности воспламенения нефтепродуктов;

- снижение опасности пролива нефтепродуктов;

- предотвращение потери качества нефтепродуктов;

- снижение временных затрат на налив;

- снижение стоимости оборудования налива;

- повышение эффективности рекуперации паров нефтепродуктов.

Ограничением применения нижнего налива нефтепродуктов в цистерны является возможная необходимость переоборудования цистерн специальными клапанами, предназначенными для герметичной стыковки с присоединительной головкой при наливе нефтепродуктов в цистерну [3].

\section{Список литературы:}

1. Применение регулируемых преобразователей для целей энергосбережения http://www.elpri.ru/pdf/Energosber_PCH.pdf

2. Асинхронный электродвигатель для частотно-регулируемого электропривода турбомеханизмов http://www.dissercat.com/content/asinkhronnyi-elektrodvigatel-dlyachastotno-reguliruemogo-elektroprivoda-turbomekhanizmov

3. Системы налива ж/д цистерн http://www.scherzer.net 